\title{
Synthesis, Spectroscopic Characterization and Pharmacological Evaluation of Schiff Base molecular Adducts of Copper metal
}

\author{
RICHA KOTHARI \\ Department of Chemistry, ITM University Gwalior, 474011, India. \\ ${ }^{*}$ Corresponding author E-mail: Richakothari70 @ gmail.com \\ http://dx.doi.org/10.13005/ojc/330340
}

(Received: February 14, 2017; Accepted: April 19, 2017)

\begin{abstract}
A series of copper complexes were prepared from $\mathrm{N}^{4}$ - substituted Schiff base ligands having structure $\left[\mathrm{Cu}(\mathrm{L})_{2}\right] \mathrm{Cl}_{2}$; where $\mathrm{L}=\mathrm{p}$-methoxy benzylidene ethylene diammine, $p$-nitro benzylidene ethylene diammine, $p$-chloro acetophenone ethylene diammine, $p$-methoxy acetophenone ethylene diammine, $\mathrm{p}$-nitro acetophenone ethylene diammine. All copper complexes were characterized by various physico- chemical techniques like melting point, TLC, elemental analysis, IR, $\mathrm{H}^{1}$-NMR, LCMS,UV-Visible spectra. The magnetic moments and electronic spectral studies suggested distorted octahedral geometry for all the complexes. The monoanionic ethylene diammine ligands act in a bi dentated mode, binding through azomethine nitrogen atoms.. The synthesized compounds were screened for their in vitro antibacterial activity using Disc Diffusion method against two strains of gram negative and gram positive bacteria. Tetracycline antibiotic was used as positive control in this test. All the compounds showed significant antibacterial activity in the range of $1-10 \mathrm{mg} / \mathrm{ml}$. Antioxidant activity of the all copper complexes was screened using the DPPH scavenging assay. In this activity ascorbic acid was used as a positive control .All complexes exhibited potent antioxidant activity in the range $50-75 \%$. These compounds would be evaluated further for their possible DNA binding, cleavage, antifungal and anti-diabetic activities.
\end{abstract}

Keywords: Copper (II) complexes, Schiff bases, Molecular adducts, Pharmacological evaluation, Invitro-antibacterial, Antioxidant activity.

\section{INTRODUCTION}

Metal-based antitumor drugs play a relevant role in antiblastic chemotherapy. Cisplatin is regarded as one of the most effective drugs, even if severe toxicities and drug resistance phenomena limit its clinical use. Therefore, in recent years there has been a rapid expansion in research and development of novel metal-based anticancer drugs to improve clinical effectiveness, to reduce general toxicity and to broaden the spectrum of activity. The variety of metal ion functions in biology has stimulated the development of new metallo drugs other than Pt drugs with the aim to obtain compounds acting via alternative mechanisms of action. Among non-Pt compounds, copper 
complexes are potentially attractive as anticancer agents. Actually, since many years a lot of researches have actively investigated copper compounds based on the assumption proposal that endogenous metals may be less toxic. It has been established that the properties of copper-coordinated compounds are largely determined by the nature of ligands and donor atoms bound to the metal ion. Organo- metallic compounds have been used in medicine for centuries. Metal play essential role in pharmaceutical industry. The metallo elements present in trace quantities play vital role at the molecular level in the system. Copper as a component of numerous enzymes is involved in energy production, is necessary for neurotransmission in the brain and is active in cell protection from the damage generated by the free radicals. The copper deficiency is associated with the anemia and bone demineralization. Copper is most abundant and essential metal in our body system. Cu(II)- based complexes. Cu(II)- based complexes appear to very promising candidates for anticancer therapy, an idea supported by a considerable number of researchers ${ }^{2-5}$ describing the synthesis and cytotoxic activities of numerous $\mathrm{Cu}$ (II) complexes and copper (II) complexes containing Schiff bases have also displayed biological properties $^{6-8}$. Schiff base macro cyclic ligands based on ethylene di ammine and its metal complexes have received considerable attention. Because of their pharmacological properties, they have numerous applications as antibacterial and anticancer agents $^{9-11}$. They can yield mono or poly nuclear complexes, some of which are biologically relevant ${ }^{12-15}$. Copper complexes can serve as models for enzymes such as galactose oxidase and may be used as effective oxidants and redox catalysts ${ }^{16-17}$. Furthermore, they allow extraction of metallic cations and anions of biochemical and environmental importance ${ }^{18-21}$. Macro cyclic ligand complexes find applications in various industries and in a number of biological processes such as photosynthesis and di oxygen transport ${ }^{22}$, catalysis, metal extractants, radiotherapy, medical imaging agents, DNA binding ${ }^{23}$ and antitumor agents. It has been known for many years that a large number of Schiff base ligands and series of their copper
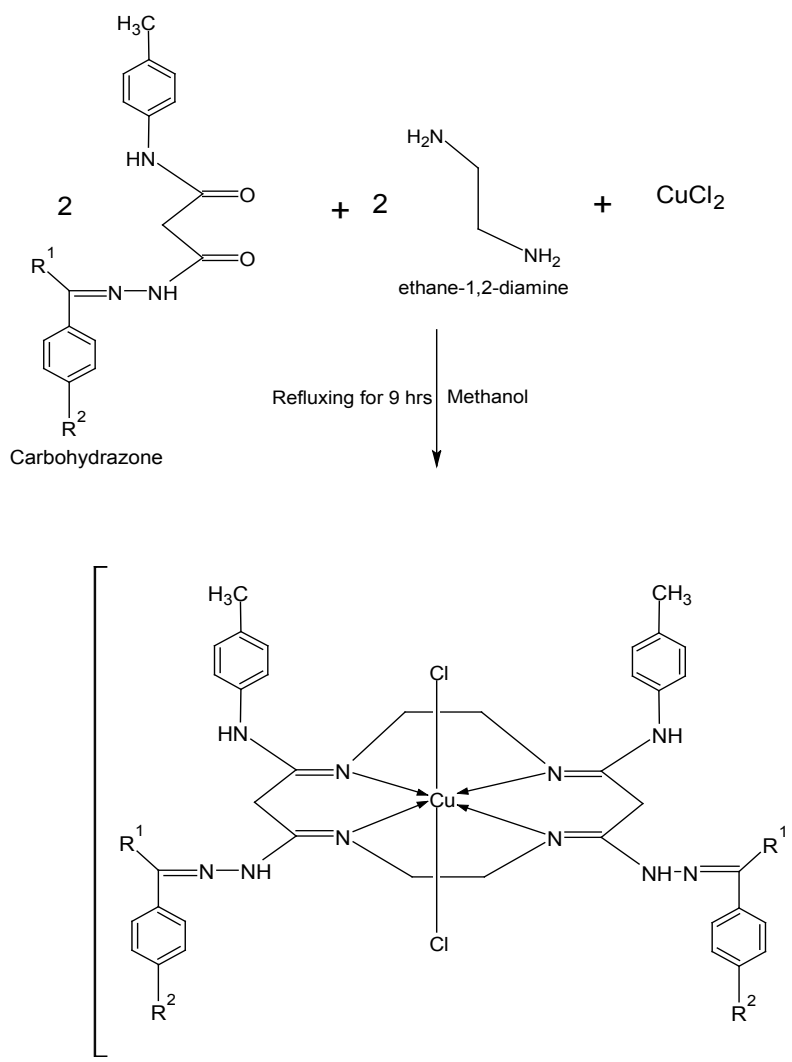

Fig. 1: Reaction scheme of schiff base molecular adducts of Copper 
complexes have promising antitumor activities ${ }^{24-26}$. A critical property of many copper (II) complexes is their poor water solubility and their relatively high in vivo toxicity ${ }^{27-28}$. Many attempts have been made to improve hydrophilicity and reduce toxicity by modifying the thiosemi carbazone framework ${ }^{29}$. In recent years, several series of copper complexes have been studied as potential antitumor agents. Although scanty information is available of the molecular basis of their mechanism of action, copper complexes have attracted attention because their probable mode of action is different from that of cisplatin. Therefore, copper complexes may provide a broader spectrum of antitumor activity. Elemental analysis and spectroscopic analysis suggested the distorted octahedral geometry for these complexes.

In this paper, the most remarkable achievements in the design and development of copper (II) complexes as antitumor agents are discussed. Special emphasis has been focused on the identification of structure-activity relationships for the different classes of copper (I, II) complexes. This work was motivated by the observation that no comprehensive surveys of copper complexes as anticancer agents were available in the literature. Moreover, up to now, despite the enormous efforts in synthesizing different classes of copper complexes, very few data concerning the molecular basis of the mechanisms underlying their antitumor activity are available. This overview, collecting the most significant strategies adopted in the last ten years to design promising anticancer copper(I,II) compounds, would be a help to the researchers working in this field.

\section{MATERIALS AND METHODS}

\section{Chemistry}

All glass wares were dried in an open flame before use in connection with an inert atmosphere. Solvents were evaporated under reduced pressure and evaporation was carried out at $<50^{\circ} \mathrm{C}$. TLC was performed using silica gel60F254 plates with iodine vapors as detecting agent. Tetra methyl silane (TMS; 0.0 ppm) was used as an internal standard in 1HNMR and Chloroform-d (CDCl3; 77.0 ppm) was used in 13C NMR. Elemental analysis was carried out on a Perkin Elmer 2400 series 11 CHNS/O elemental analyzer. FTIR spectra were recorded using $\mathrm{KBr}$ pellets on Perkin Elmer-Spectrum $\mathrm{RX}$-IFTIR in the $4000-250 \mathrm{~cm}-1$ region. The electronic spectra in DMSO solution were obtained with a Hitachi 330 uv- vis- nir spectro photo meter. The FAB- Masses in positive mode were recorded on a Waters Micro mass Q-Tof spectrometer; m-Nitro benzyl alcohol (m-NOBA) was used as the matrix. Melting points were determined by open capillary method. All materials were obtained from commercial suppliers such as Merck, CDH, SRL and were used without further purification. The solvents and copper salts used were of analytical grade. Various hydrazones of complexation agent were prepared by standard methods described in the literature ${ }^{30}$.

\section{Synthesis of Schiff base molecular adducts of copper metal}

A mixture of hydrated copper chloride, compound (1-5) and ethylenediammine hydrochloride in 2:2:1 molar ratio in absolute ethanol were added slowly with stirring in a round bottom flaskat $70-80^{\circ} \mathrm{C}$ for 8 hours. Solvent was evaporated under reduced pressure and the residue obtained was quenched with ethanol. The solid product was precipitated, filtered off, washed several times with cold ethanol and dried over fused $\mathrm{CaCl}_{2}$ in desiccators. A good yield of product was obtained and the purity of the complex was confirmed by the TLC and the elemental analysis.

Where $R^{1}$ and $R^{2}$ substitutions are as follows :-

\begin{tabular}{lccc}
\hline S.No. & Compound & $\mathbf{R}^{\mathbf{1}}$ & $\mathbf{R}^{\mathbf{2}}$ \\
\hline 1. & {$\left[\mathrm{Cu}(\mathrm{p} \text {-macehen })_{2}\right] \mathrm{Cl}_{2}$} & $-\mathrm{CH}_{3}$ & $-\mathrm{OCH}_{3}$ \\
2. & {$\left[\mathrm{Cu}(\mathrm{p} \text {-nacehen })_{2}\right] \mathrm{Cl}_{2}$} & $-\mathrm{CH}_{3}$ & $-\mathrm{NO}_{2}$ \\
3. & {$\left[\mathrm{Cu}(\mathrm{p} \text {-clbhen })_{2}\right] \mathrm{Cl}_{2}$} & $-\mathrm{H}$ & $-\mathrm{Cl}$ \\
4. & {$\left[\mathrm{Cu}(\text { pmbhen })_{2}\right] \mathrm{Cl}_{2}$} & $-\mathrm{H}$ & $-\mathrm{OCH}_{3}$ \\
5. & {$\left[\mathrm{Cu}(\mathrm{p} \text {-nbhen })_{2}\right] \mathrm{Cl}_{2}$} & $-\mathrm{H}$ & $-\mathrm{NO}_{2}$ \\
\hline
\end{tabular}

[Cu (p-macehen) ${ }_{2} \mathrm{Cl}_{2}$; bis (p-methoxy aceto phenone ethylene di ammine) copper II chloride

Yield: $50 \%$; $\mathrm{mp} 225^{\circ} \mathrm{C}$; IR (KBr) (cm-1): 3299, 3034, 1581, 530; ${ }^{\mathrm{H}} \mathrm{H}-\mathrm{NMR}$ (TMS) (ppm): 2.56, 2.67-2.68, 3.96-4.02 and 6.7-6.96; ESI MS: 861.5 (observed peak) other peak, 791.2, 730, 222.1, 154.1 a.m.u.; Anal. Calcd for $\left[\mathrm{Cu}\left(\mathrm{C}_{42} \mathrm{H}_{50} \mathrm{~N}_{10} \mathrm{O}_{2}\right)\right] \mathrm{Cl}_{2}$ 
; $\mathrm{C}=58.56 ; \mathrm{H}=5.81 ; \mathrm{N}=16.26$. Found: $\mathrm{C}=57.84$; $\mathrm{H}=5.97 ; \mathrm{N}=15.76 ; \lambda_{\max }=365$; Molar conductance $=46.5 \mathrm{ohm}^{-1} \mathrm{~cm}^{2} \mathrm{mho}^{-1}$

[Cu (p-nacehen) $)_{2} \mathrm{Cl}_{2}$; bis (p-nitroacetophenone ethylene diammine) copper II chloride

Yield: $76 \%$; mp $240{ }^{\circ} \mathrm{C}$; IR (KBr) $(\mathrm{cm}-1)$ : 3231, 3034, 1581, 534; ${ }^{1} \mathrm{H}-\mathrm{NMR}$ (TMS) (ppm): 1.1, 2.1-2.25, 3.60-3.67, 7.35-8.03; ESI-MS: 891.5 (molecular ion peak) other peak 821.3, 510.3, 400.7, 300.3, 103.2 a.m.u; Anal. Calcd for $\left[\mathrm{Cu}\left(\mathrm{C}_{40} \mathrm{H}_{44} \mathrm{~N}_{12} \mathrm{O}_{4}\right)\right]$ $\mathrm{Cl}_{2} ; \mathrm{C}=53.89 ; \mathrm{H}=4.94 ; \mathrm{N}=18.86$. Found: $\mathrm{C}=53.56$; $\mathrm{H}=4.73 ; \mathrm{N}=17.51 ; \lambda_{\text {max }}=390 ;$ Molar conductance $=38.25 \mathrm{ohm}^{-1} \mathrm{~cm}^{2} \mathrm{mho}^{-1}$

[Cu (p-clbhen) $)_{2} \mathrm{Cl}_{2}$; bis (p-chlorobenzylidene ethylene diammine) copper II chloride

Yield: $40 \%$; mp $310{ }^{\circ} \mathrm{C}$; IR (KBr) (cm-1): 3299, 3038, 1621, 494; ${ }^{1} \mathrm{H}-\mathrm{NMR}$ (TMS) (ppm): 2.1, 2.23-2.34, 3.11-3.12 and 6.81-7.9; ESI-MS: 846.3 (molecular ion peak) other peak 796.1, 490.1, 283.2, 103.0 a.m.u; Anal. Calcd for $\left[\mathrm{Cu}\left(\mathrm{C}_{38} \mathrm{H}_{40} \mathrm{~N}_{10} \mathrm{Cl}_{2}\right)\right] \mathrm{Cl}_{2}$; $\mathrm{C}=54.18 ; \mathrm{H}=4.75 ; \mathrm{N}=16.63$. Found: $\mathrm{C}=54.21$; $\mathrm{H}=4.26 ; \mathrm{N}=16.79 . \lambda_{\text {max }}=386$; Molar conductance $=53.35 \mathrm{ohm}^{-1} \mathrm{~cm}^{2} \mathrm{mho}^{-1}$

$\mathrm{Cu}$ (pmbhen) ${ }_{2} \mathrm{Cl}_{2}$; bis ( $p$-methoxybenzylidene ethylene diammine) copper II chloride

Yield: $60 \%$; mp $165{ }^{\circ} \mathrm{C}$; IR (KBr) $(\mathrm{cm}-1)$ : 3284, 2965, 1607, 522; ${ }^{1} \mathrm{H}-\mathrm{NMR}$ (TMS) (ppm): 1.8, 2.48-2.50, 3.42 and 7.01-7.36; ESI-MS: 831.1 (Molecular ion peak) other peak 665.1, 405.0,
192.1 a.m.u.; Anal. Calcd for $\left[\mathrm{Cu}\left(\mathrm{C}_{40} \mathrm{H}_{46} \mathrm{~N}_{10} \mathrm{O}_{2}\right)\right] \mathrm{Cl}_{2}$; $\mathrm{C}=57.64 ; \mathrm{H}=5.52 ; \mathrm{N}=16.81$. Found: $\mathrm{C}=57.12$; $\mathrm{H}=5.89 ; \mathrm{N}=16.82 ; \lambda_{\text {max }}=395$; Molar conductance $=23.15 \mathrm{ohm}^{-1} \mathrm{~cm}^{2} \mathrm{mho}^{-1}$

Cu (p-nbhen) $)_{2} \mathrm{Cl}_{2}$; bis (p-nitrobenzylidene ethylene diammine) copper II chloride

Yield: $48 \% \mathrm{mp} 230{ }^{\circ} \mathrm{C}$; IR $(\mathrm{KBr})(\mathrm{cm}-1)$ : 3345, 3030, 1597, 530; ${ }^{1} \mathrm{H}-\mathrm{NMR}$ (TMS) (ppm): 2.15, 2.51, 3.18-3.5 and 7.45-8.11; ESI-MS: 732.1 (Molecular ion peak) 551.1, 378.1, 219.1 a.m.u.; Anal. Calcd for $\left[\mathrm{Cu}\left(\mathrm{C}_{38} \mathrm{H}_{40} \mathrm{~N}_{12} \mathrm{O}_{4}\right)\right] \mathrm{Cl}_{2} ; \mathrm{C}=52.86$; $\mathrm{H}=4.63 ; \mathrm{N}=19.47$. Found: $\mathrm{C}=51.78 ; \mathrm{H}=4.77$; $\mathrm{N}=19.37 ; \lambda_{\max }=410 ;$ Molar conductance $=26.250 \mathrm{hm}^{-1} \mathrm{~cm}^{2} \mathrm{mho}^{-1}$

\section{In-vitro Antibacterial Activity}

The in vitro antibacterial effects of copper complexes were evaluated against two sp. of Grampositive bacteria (Staphylococcus aureus (MTCC 3160) and B. Subtilis (MTCC 1134)) and two Gramnegative bacteria (Escherichia coli (MTCC 50), Pseudomonas aeruginosa (MTCC 1034) by the disc diffusion method using nutrient agar medium. The bacteria were sub-cultured in the agar medium and were incubated for $24 \mathrm{~h}$ at $37^{\circ} \mathrm{C}$. The discs having a diameter of $5 \mathrm{~mm}$, were then soaked in the test solutions (Sterile filter paper discs, What man No. 1.0) with the equivalent amount of semicarbazide $\mathrm{Cu}$ (II) complexes dissolved in sterile dimethyl sulphoxide (DMSO) at concentrations of $10 \mathrm{mg} / \mathrm{mL}$ and were placed in petri dishes on an appropriate

Table 1: Physical and Analytical data of Copper (II) complexes of Schiff base molecular adducts

\begin{tabular}{|c|c|c|c|c|c|c|c|c|c|c|c|}
\hline \multirow[t]{3}{*}{ S.No. } & \multirow{3}{*}{$\begin{array}{l}\text { Comp- } \\
\text { ounds }\end{array}$} & \multirow{3}{*}{$\begin{array}{l}\text { Molecular } \\
\text { Formula }\end{array}$} & \multirow[t]{3}{*}{ Color } & \multirow[t]{3}{*}{ Yield } & \multirow{3}{*}{$\begin{array}{l}\text { M.P. } \\
\left({ }^{\circ} \mathrm{C}\right)\end{array}$} & \multirow{3}{*}{ Mol.wt. } & \multirow{3}{*}{$\begin{array}{c}\text { Molar } \\
\text { conduct } \\
\Omega^{-1} \mathrm{~cm}^{2} \\
\mathrm{~mol}^{-1}\end{array}$} & \multirow{2}{*}{\multicolumn{2}{|c|}{$\begin{array}{l}\text { Analysis (\%) } \\
\text { ce } \quad \text { (Calcd.) }\end{array}$}} & \multirow[t]{2}{*}{ Found } & \multirow[t]{3}{*}{$\lambda_{\max }$} \\
\hline & & & & & & & & & & & \\
\hline & & & & & & & & $\mathrm{C} \%$ & $\mathbf{H} \%$ & $\mathrm{~N} \%$ & \\
\hline 1. & $A$ & $\begin{array}{l}{\left[\mathrm{Cu}\left(\mathrm{C}_{42} \mathrm{H}_{50}\right.\right.} \\
\left.\left.\mathrm{N}_{10} \mathrm{O}_{2}\right)\right] \mathrm{Cl}_{2}\end{array}$ & Green & 65 & 225 & 860.54 & 46.5 & $\begin{array}{l}57.84 / \\
58.56\end{array}$ & $\begin{array}{l}5.97 / \\
5.81\end{array}$ & $\begin{array}{l}15.76 / \\
16.26\end{array}$ & $365 \mathrm{~nm}$ \\
\hline 2. & B & $\begin{array}{l}{\left[\mathrm{Cu}\left(\mathrm{C}_{40} \mathrm{H}_{44}\right.\right.} \\
\left.\left.\mathrm{N}_{12} \mathrm{O}_{4}\right)\right] \mathrm{Cl}_{2}\end{array}$ & Green & 76 & 240 & 890.54 & 38.2 & $\begin{array}{l}53.56 / \\
53.89\end{array}$ & $\begin{array}{l}4.73 / \\
4.94\end{array}$ & $\begin{array}{l}17.51 / \\
18.86\end{array}$ & $390 \mathrm{~nm}$ \\
\hline 3. & $\mathrm{C}$ & $\begin{array}{l}{\left[\mathrm{Cu}\left(\mathrm{C}_{38} \mathrm{H}_{40}\right.\right.} \\
\left.\left.\mathrm{N}_{10} \mathrm{Cl}_{2}\right)\right] \mathrm{Cl}_{2}\end{array}$ & Green & 40 & 310 & 841.54 & 53.3 & $\begin{array}{l}54.21 / \\
54.18\end{array}$ & $\begin{array}{l}4.26 / \\
4.75\end{array}$ & $\begin{array}{l}16.79 / \\
16.63\end{array}$ & $386 \mathrm{~nm}$ \\
\hline 4.. & $D$ & $\begin{array}{l}{\left[\mathrm{Cu}\left(\mathrm{C}_{40} \mathrm{H}_{46}\right.\right.} \\
\left.\left.\mathrm{N}_{10} \mathrm{O}_{2}\right)\right] \mathrm{Cl}_{2}\end{array}$ & Cream & 60 & 165 & 832.54 & 23.1 & $\begin{array}{l}57.12 / \\
57.64\end{array}$ & $\begin{array}{l}5.89 / \\
5.52\end{array}$ & $\begin{array}{l}16.82 / \\
16.81\end{array}$ & $395 \mathrm{~nm}$ \\
\hline 5.. & $E$ & $\begin{array}{l}{\left[\mathrm{Cu}\left(\mathrm{C}_{38} \mathrm{H}_{40}\right.\right.} \\
\left.\left.\mathrm{N}_{12} \mathrm{O}_{4}\right)\right] \mathrm{Cl}_{2}\end{array}$ & $\begin{array}{l}\text { Greenish } \\
\text { yellow }\end{array}$ & 48 & 230 & 862.54 & 26.2 & $\begin{array}{l}51.78 / \\
52.86\end{array}$ & $\begin{array}{l}4.77 / \\
4.63\end{array}$ & $\begin{array}{l}19.37 / \\
19.47\end{array}$ & $410 \mathrm{~nm}$ \\
\hline
\end{tabular}


medium previously seeded with microbial organisms and stored in an incubator for $24 \mathrm{hrs}$. The inhibition zone around each disc was measured and the results were recorded in the form of inhibition zones (diameter, $\mathrm{mm}$ ). To clarify any effect of DMSO on the biological screening, separate studies were carried out using DMSO as negative control and it showed no activity against any bacterial strains. Tetracycline was used as a positive control in this antibacterial analysis.

\section{In-vitro Antioxidant Activity}

The free radical scavenging activity (RSA) of copper complexes at concentration $200,400,600$, $800,1000 \mu \mathrm{g} / \mathrm{ml}$ was carried out in presence of freshly prepared solution of stable free radical DPPH $(0.04 \%$ w/v) following Hataro's method using ascorbic acid as standard. All the test analysis was performed on three triplicates and results are averaged. The results in percentage are expressed as the ratio of absorption decrease of DPPH in the

Table 2: The Relevant IR peaks of copper (II) complexes of Schiff base molecular adducts

\begin{tabular}{|c|c|c|c|c|c|}
\hline $\begin{array}{l}\text { S. } \\
\text { No. }\end{array}$ & pou & \multicolumn{2}{|c|}{$v(\mathbf{N}-\mathbf{H}) v(\mathbf{A r}-\mathbf{H})$} & $v(\mathbf{C}=\mathbf{N})$ & $v(\mathbf{C u}-\mathbf{N})$ \\
\hline 1. & $A$ & 3299 & 3034 & 1581 & 530 \\
\hline 2. & B & 3231 & 3034 & 1581 & 534 \\
\hline 3. & C & 3299 & 3038 & 1621 & 494 \\
\hline 4. & $D$ & 3284 & 2965 & 1607 & 522 \\
\hline 5. & $E$ & 3245 & 3030 & 1597 & 530 \\
\hline
\end{tabular}

Table 3: The Relevant ${ }^{1} \mathrm{H}-\mathrm{NMR}$ peaks of copper (II) complexes of Schiff base molecular adducts

\section{S. Compounds $\delta \mathrm{CH}_{3} \quad \delta \mathrm{CH}_{2} \delta \mathrm{NH} \delta \mathbf{C}_{6} \mathbf{H}_{5}$} No.

\begin{tabular}{lccccc} 
1. & $\mathrm{A}$ & 2.56 & $2.67-$ & $3.96-$ & $6.7-$ \\
& & & 2.68 & 4.02 & 6.96 \\
2. & $\mathrm{B}$ & 1.1 & $2.1-$ & $3.60-$ & $7.35-$ \\
& & & 2.25 & 3.67 & 8.03 \\
3. & $\mathrm{C}$ & 2.1 & $2.23-$ & $3.11-$ & $6.81-$ \\
& & & 2.34 & 3.12 & 7.9 \\
4. & $\mathrm{D}$ & 1.8 & $2.48-$ & 3.42 & $7.01-$ \\
& & & 2.50 & & 7.36 \\
5 & $\mathrm{E}$ & 2.15 & 2.51 & $3.18-$ & $7.45-$ \\
& & & & 3.5 & 8.11 \\
\hline
\end{tabular}

presence of test compounds and absorption of DPPH in the absence of test compounds at $517 \mathrm{~nm}$ by UV Visible spectro photo meter. The percentage scavenging activity of the DPPH free radical was measured using following equation-

$\%$ RSA $=\frac{A_{C}-A_{S}}{A_{C}} \times 100$

Where, $A_{C}=$ Absorbance of control. $A_{S}=$ Absorbance of test Sample

\section{In-vitro Antineoplastic Activity}

The monolayer cell culture was trypsinized and the cell count was adjusted to $1.0 \times 10^{5} \mathrm{cells} /$ $\mathrm{ml}$ using DMEM containing 10\% FBS. To each well of the 96 well microtitre plate, $0.1 \mathrm{ml}$ of the diluted cell suspension (approximately 10,000 cells) was added. After $24 \mathrm{~h}$, when a partial monolayer was formed, the supernatant was flicked off, washed the monolayer once with medium and $100 \mu$ of different test concentrations of test drugs were added on to the partial monolayer in microtitre plates. The plates were then incubated at $37^{\circ} \mathrm{C}$ for 3 days in $5 \% \mathrm{CO}_{2}$ atmosphere, and microscopic examination was carried out and observations were noted every 24 $\mathrm{h}$ interval. After $72 \mathrm{~h}$, the drug solutions in the wells were discarded and $50 \mu$ of MTT in PBS was added to each well. The plates were gently shaken and incubated for $3 \mathrm{~h}$ at $37^{\circ} \mathrm{C}$ in $5 \% \mathrm{CO}_{2}$ atmosphere. The supernatant was removed and $100 \mu$ of propanol was added and the plates were gently shaken to solubilize the formed formazan. The absorbance was measured using a microplate reader at a wavelength of $540 \mathrm{~nm}$. The percentage growth inhibition was calculated using the following formula and concentration of test drug needed to inhibit cell growth by $50 \%\left(\mathrm{CTC}_{50}\right)$ values is generated from the dose-response curves for each cell line ${ }^{119}$.

$\%$ Growth Inhibition $=100-\frac{\text { Mean OD of individual test group }}{\text { Mean OD of control }} \times 100$

The Human Breast Carcinoma Cell Line; MCF-7 Cells were obtained from the National Center for Cell Science (NCCS), Pune India. Cells were cultured in DMEM supplemented with $10 \%$ FBS, 100U/I Penicillin, 200mg/l Streptomycin \& 50mg/l Gentamicin maintained at $37^{\circ} \mathrm{C}$ in a humidified $5 \% \mathrm{CO}_{2}$ Incubator. For experiments, cells were trypsinized and cultured in 6-well $\left(0.2 \times 10^{6}\right.$ 
cells/well) and 96 -well ( $1.0 \times 10^{4} /$ well) plates initially for $48 \mathrm{~h}$ so as to allow the cells to attach. After $48 \mathrm{~h}$, the cells were exposed to various concentrations of complexes for the next $48 \mathrm{~h}$. Each dose was tested in at least triplicate wells.

\section{RESULT AND DISCUSSION}

All copper complexes were synthesized by the template method. Carbohydrazone, ethylene di ammine hydrochloride and $\mathrm{CuCl}_{2} \cdot 2 \mathrm{H}_{2} \mathrm{O}$ were taken in 2:2:1 molar ratio in round bottom flask. All the complexes are stable to the atmosphere and had high melting points. Elemental analysis; $\mathrm{C}, \mathrm{H}$ and $\mathrm{N}$ of the complexes were evaluated from SAIF, Punjab University, Chandigarh and the low molar conductance values of all the complexes in DMSO at room temperature indicated them to be non electrolytic in nature. All complexes are completely soluble in DMF, DMSO and ethanol but insoluble in water. The copper content was determined by the EDTA titration method and the nitrogen content of the complexes was determined by Kjeldahl's method.

\section{LC - MS Study}

Transition metal complexes were recorded under liquid secondary ion mass spectral condition. All the spectra exhibited parent ion peaks due to molecular ions $[\mathrm{M}]^{+}$.

- $\quad$ Compound (A) exhibits molecular ion peak at 861.5 that are corresponding to molecular ion peak and it gives a peak at 222.1 that is corresponding to base ion peak with $99 \%$ intensity. This compound also gives other peaks at 791.2, 730, 503.2, 350, 496.3 and 154.1. The spectrum exhibited other peaks assignable to various fragments arising from the thermal cleavage of the complexes. The peak intensities give an idea of a stability of the fragment that showed at 222.1.

- $\quad$ Compound (B) exhibit molecular ion peak at 891.5 and other fragments of this compound is arised at 821.3, 510.3, 400.7, 345.1, 300.3, 296.3 and 106.0. This compound give base ion peak at 103.2 with $80 \%$ intensity. In addition to the molecular ion peaks, the spectrum exhibited other peaks assignable to various fragments arising from the thermal cleavage of the complexes. The peak intensities given an idea of a stability of the fragment that showed at 103.2.

Compound (C) exhibited molecular ion peak at 846.3 and other peaks of the compound $6 \mathrm{~d}$ observed at 796.1, 490.1, 400.2, 283.4, 223.1, 103.0 etc. This compound observed maximum intensities at 283.4 that are corresponding to base ion peaks. In addition to the molecular ion peak, the spectrum exhibited other peaks assignable to various fragments arising from the thermal cleavage of the complexes. The peak intensities given an idea of a stability of the fragment that showed at 283.4.

Compound (D) showed molecular ion peak at 831.1 that is corresponding to molecular ion peak and it gives base ion peak at 192.1 with $100 \%$ intensity. The other peak of compound 6 e observed at 665.1, 405.2, 361.4, 340.3, $275.3,192.1,104.0$ etc. In addition to the molecular ion peak, the spectrum exhibited other peaks assignable to various fragments arising from the thermal cleavage of the complexes. The peak intensities given an idea of a stability of the fragment that showed at 192.1.

Compound (E) give molecular ion peak at 849.1 and other peaks of the compound at 732.1, 551.1, 378.1, 338.2, 219.1, 249.1 etc. The compound $6 f$ observed base ion peaks at 378.1. In addition to the molecular ion peak, the spectrum exhibited other peaks assignable to various fragments arising from the thermal cleavage of the complexes. The peak intensities given an idea of a stability of the fragment that showed at 378.1.

\section{Infrared Spectra}

The main IR vibration bands of all copper complexes are listed in Table 2. Upon coordination, change in the frequency $v(\mathrm{C}=\mathrm{N})$ and $v(\mathrm{~N}-\mathrm{H})$ wave numbers in comparison to the values found for the macrocyclic ethylene diammine ligands were observed for complexes a-f. They are consistent with the tetra dentate coordination of the ligand through the azomethine nitrogen atom.

Compound (A) exhibit a peak on $3299 \mathrm{~cm}^{-1}$ which confirm that it contain $v(\mathrm{~N}-\mathrm{H})$ group and it show a band on $3034 \mathrm{~cm}^{-1}$ correspond to aromatic $\mathrm{C}-\mathrm{H}$; compound exhibit a band on $1581 \mathrm{~cm}^{-1}$ which 
correspond to $v(\mathrm{C}=\mathrm{N})$, the shifting of $v(\mathrm{C}=\mathrm{N})$ band from 1650 to 1581 ; which confirmed the coordination occur through the azomethine group, the compound observed a band on $530 \mathrm{~cm}^{-1}$ indicates that a bond form in between $v(\mathrm{Cu}-\mathrm{N})$. The occurrence of the $v(\mathrm{~N}-\mathrm{N})$ band at higher frequencies in the IR spectrum of the complexes as compared to those observed for the ligands, confirmed coordination through the azomethine nitrogen atom. The spectrum does not exhibit any band at the $1684 \mathrm{~cm}^{-1}$ frequency which was observed in compound $3(\mathrm{~b})$ indicates that condensation occurs in between $v(C=O)$ group of ligand and $\mathrm{NH}_{2}$ group of ethylene diammine.

Compound (B) exhibit a peak on $3231 \mathrm{~cm}^{-1}$ which confirm that it contain $v(\mathrm{~N}-\mathrm{H})$ group and it show a band on $3034 \mathrm{~cm}^{-1}$ correspond to aromatic $\mathrm{C}-\mathrm{H}$; compound exhibit a band on $1581 \mathrm{~cm}^{-1}$ which correspond to $v(\mathrm{C}=\mathrm{N})$, the shifting of $v(\mathrm{C}=\mathrm{N})$ band from 1640 to 1581 ; which confirmed the coordination occur through the azomethine group, the compound observed a band on $534 \mathrm{~cm}^{-1}$ indicates that a bond form in between $v(\mathrm{Cu}-\mathrm{N})$. The occurrence of the $v(\mathrm{~N}-\mathrm{N})$ band at higher frequencies in the IR spectrum of the complexes as compared to those observed for the ligands, confirmed coordination through the azomethine nitrogen atom. The spectrum does not exhibit any band at the $1692 \mathrm{~cm}^{-1}$ frequency which was observed in compound 3(c) indicates that condensation occurs in between $v(\mathrm{C}=\mathrm{O})$ group of ligand and $\mathrm{NH}_{2}$ group of ethylene diammine.

Compound (C) exhibit a peak on $3299 \mathrm{~cm}^{-1}$ which confirm that it contain $v(\mathrm{~N}-\mathrm{H})$ group and it show a band on $3038 \mathrm{~cm}^{-1}$ correspond to aromatic $\mathrm{C}-\mathrm{H}$; compound exhibit a band on $1621 \mathrm{~cm}^{-1}$ which correspond to $v(\mathrm{C}=\mathrm{N})$, the shifting of $v(\mathrm{C}=\mathrm{N})$ band from 1650 to 1621 ; which confirmed the coordination occur through the azomethine group, the compound observed a band on $494 \mathrm{~cm}^{-1}$ indicates that a bond form in between $v(\mathrm{Cu}-\mathrm{N})$. The occurrence of the $v(\mathrm{~N}-\mathrm{N})$ band at higher frequencies in the IR spectrum of the complexes as compared to those observed for the ligands, confirmed coordination through the azomethine nitrogen atom. The spectrum does not exhibit any band at the $1684 \mathrm{~cm}^{-1}$ frequency which was observed in compound 4(a) indicates that condensation occurs in between $v(\mathrm{C}=\mathrm{O})$ group of ligand and $\mathrm{NH}_{2}$ group of ethylene diammine.
Compound (D) exhibit a peak on $3284 \mathrm{~cm}^{-1}$ which confirm that it contain $v(\mathrm{~N}-\mathrm{H})$ group and it show a band on $2965 \mathrm{~cm}^{-1}$ correspond to aromatic $\mathrm{C}-\mathrm{H}$; compound exhibit a band on $1607 \mathrm{~cm}^{-1}$ which correspond to $v(\mathrm{C}=\mathrm{N})$, the shifting of $v(\mathrm{C}=\mathrm{N})$ band from 1651 to $1607 \mathrm{~cm}^{-1}$; which confirmed the coordination occur through the azomethine group, the compound observed a band on $522 \mathrm{~cm}^{-1}$ indicates that a bond form in between $v(\mathrm{Cu}-\mathrm{N})$. The occurrence of the $v(\mathrm{~N}-\mathrm{N})$ band at higher frequencies in the IR spectrum of the complexes as compared to those observed for the ligands, confirmed coordination through the azomethine nitrogen atom. The spectrum does not exhibit any band at the $1690 \mathrm{~cm}^{-1}$ frequency which was observed in compound $4(\mathrm{~b})$ indicates that condensation occurs in between $v(\mathrm{C}=\mathrm{O})$ group of ligand and $\mathrm{NH}_{2}$ group of ethylene diammine.

Compound (E) exhibit a peak on $3245 \mathrm{~cm}^{-1}$ which confirm that it contain $v(\mathrm{~N}-\mathrm{H})$ group and it show a band on $3030 \mathrm{~cm}^{-1}$ correspond to aromatic $\mathrm{C}-\mathrm{H}$; compound exhibit a band on $1597 \mathrm{~cm}^{-1}$ which correspond to $v(\mathrm{C}=\mathrm{N})$, the shifting of $v(\mathrm{C}=\mathrm{N})$ band from 1655 to $1597 \mathrm{~cm}^{-1}$; which confirmed the coordination occur through the azomethine group, the compound observed a band on $530 \mathrm{~cm}^{-1}$ indicates that a bond form in between $v(\mathrm{Cu}-\mathrm{N})$. The occurrence of the $v(\mathrm{~N}-\mathrm{N})$ band at higher frequencies in the IR spectrum of the complexes as compared to those observed for the ligands, confirmed coordination through the azomethine nitrogen atom.

\section{H-NMR Spectra}

The ${ }^{1} \mathrm{H}-\mathrm{NMR}$ spectra of the complexes were obtained in $\mathrm{CDCl}_{3}$ at room temperature using TMS as an internal standard. The main peaks observed in spectra are given in table 3.

Complex (A) observed a peak at $\delta 2.56$ ppm in ${ }^{1} \mathrm{H}$-NMR spectrum, which is corresponding to methyl group; aliphatic $-\mathrm{CH}_{2}$ group obtained singlet in between $\delta 2.67-2.68$ ppm. The ${ }^{1} \mathrm{H}$ NMR spectrum of metal complexes showed signals corresponding to $-\mathrm{NH}$ at the $\delta 3.96-4.02 \mathrm{ppm}$. The multiplets observed in the region $\delta 6.7-6.96$ ppm were assigned to the aromatic ring protons of carbohydrazone and the ethylene diammine moiety. The ${ }^{1} \mathrm{H}-\mathrm{NMR}$ spectrum of copper chelates confirmed the participation of imino - $\mathrm{NH}$ group in 
the coordination with copper ions. Some hydrogen atom values of $\delta$ were not observed precisely due to overlapping with the signals of the aromatic hydrogen atoms of carbohydrazone moiety. ${ }^{1} \mathrm{H}-\mathrm{NMR}$ integration and signal multiplicity were found to support the proposed structures.

Complex (B) a peak at $\delta 1.1 \mathrm{ppm}$ in ${ }^{1} \mathrm{H}-\mathrm{NMR}$ spectrum, which is corresponding to methyl group; aliphatic $-\mathrm{CH}_{2}$ group obtained singlet at $\delta 2.1-2.25 \mathrm{ppm}$. The multiplets observed in the region $\delta 7.35-8.03 \mathrm{ppm}$ were assigned to the aromatic ring protons of carbohydrazone and the ethylene diammine moieties. The ${ }^{1} \mathrm{H}-\mathrm{NMR}$ spectra of copper complexes showed signals corresponding to $-\mathrm{NH}$ at the $\delta 3.60-3.67 \mathrm{ppm}$. The ${ }^{1} \mathrm{H}-\mathrm{NMR}$ spectrum of copper chelates confirmed the participation of imino -NH group in the coordination with copper ions. Some hydrogen atom values of $\delta$ were not observed precisely due to overlapping with the signals of the aromatic hydrogen atoms of carbohydrazone moiety. ${ }^{1} \mathrm{H}-\mathrm{NMR}$ integration and signal multiplicity were found to proposed structure.

The ${ }^{1} \mathrm{H}-\mathrm{NMR}$ spectrum of complex (C) which showed singlet at $\delta 2.23-2.34 \mathrm{ppm}$ that are correspond to aliphatic $-\mathrm{CH}_{2}$ group. Spectrum observed a peak at $\delta 2.1 \mathrm{ppm}$ in ${ }^{1} \mathrm{H}$-NMR spectrum, which is corresponding to methyl group. The multiplets observed in the region $\delta 6.81-7.9 \mathrm{ppm}$ were assigned to the aromatic ring protons of carbohydrazone and the ethylene diammine moieties. The ${ }^{1} \mathrm{H}-\mathrm{NMR}$ spectrum of copper complexes showed signals corresponding to $-\mathrm{NH}$ at the $\delta 3.11-3.12$ ppm. The ${ }^{1} \mathrm{H}-\mathrm{NMR}$ spectrum of copper chelates confirmed the participation of imino - $\mathrm{NH}$ group in the coordination with copper ions. Some hydrogen atom values of $\delta$ were not observed precisely due to overlapping with the signals of the aromatic hydrogen atoms of carbo hydrazone moiety. ${ }^{1} \mathrm{H}-\mathrm{NMR}$ integration and signal multiplicity were found to be in agreement with the proposed structure.

Complex (D) observed a peak at $\delta 1.8 \mathrm{ppm}$, which is corresponding to methyl group; aliphatic $-\mathrm{CH}_{2}$ group obtained singlet at $\delta 2.48-2.50$ ppm in the spectrum. The multiplets observed in the region $\delta 7.01-7.31 \mathrm{ppm}$ were assigned to the aromatic ring protons of carbohydrazone and the ethylene diammine moieties. The ${ }^{1} \mathrm{H}-\mathrm{NMR}$ spectrum of copper complexes showed signals corresponding to $-\mathrm{NH}$ at the $\delta 3.42 \mathrm{ppm}$. The ${ }^{1} \mathrm{H}-\mathrm{NMR}$ spectrum of copper chelates confirmed the participation of imino $-\mathrm{NH}$ group in the coordination with copper ions. Some hydrogen atom values of $\delta$ were not observed precisely due to overlapping with the signals of the aromatic hydrogen atoms of carbohydrazone moiety. ${ }^{1} \mathrm{H}-\mathrm{NMR}$ integration and signal multiplicity were found to be in agreement with the proposed structure.

Complex (E) observed a peak at $\delta 2.15$ ppm in ${ }^{1} \mathrm{H}$-NMR spectrum, which are corresponding to methyl group; aliphatic $-\mathrm{CH}_{2}$ group obtained singlet at $\delta 2.51 \mathrm{ppm}$ in the ${ }^{1} \mathrm{H}-\mathrm{NMR}$ spectrum. The multiplets observed in the region $\delta 7.45-8.11$ ppm were assigned to the aromatic ring protons of carbohydrazone and the ethylene diammine moieties. The ${ }^{1} \mathrm{H}$-NMR spectrum of copper complexes showed signals corresponding to $-\mathrm{NH}$ at the $\delta 3.18-3.5$ ppm. The ${ }^{1} \mathrm{H}-\mathrm{NMR}$ spectrum of copper chelates confirmed the participation of imino - $\mathrm{NH}$ group in the coordination with copper ions. Some hydrogen atom values of $\delta$ were not observed precisely due to overlapping with the signals of the aromatic hydrogen atoms of carbohydrazone moiety. ${ }^{1} \mathrm{H}-\mathrm{NMR}$ integration and signal multiplicity were found to be in agreement with the proposed structure.

\section{In-vitro Antineoplastic Activity}

MCF-7 (Human Breast carcinoma) cell line was procured from National Centre for Cell Sciences (NCCS), Pune, India. Stock cells were cultured in DMEM supplemented with $10 \%$ inactivated Fetal Bovine Serum (FBS), penicillin (100 IU/ $\mathrm{ml})$, streptomycin $(100 \mu \mathrm{g} / \mathrm{ml})$ and amphotericin $\mathrm{B}(5 \mu \mathrm{g} / \mathrm{ml})$ in an humidified atmosphere of $5 \% \mathrm{CO}_{2}$ at $37^{\circ} \mathrm{C}$ until confluent. The cells were dissociated with TPVG solution (0.2\% trypsin, $0.02 \%$ EDTA, $0.05 \%$ glucose in PBS). The stock cultures were grown in 25 $\mathrm{cm}^{2}$ culture flasks and all experiments were carried out in 96 microtitre plates (Tarsons India Pvt. Ltd., Kolkata, India).

\section{Preparation of Test Solutions}

For Cytotoxicity studies, each weighed test drugs were separately dissolved in distilled DMSO and volume was made up with DMEM supplemented with $2 \%$ inactivated FBS to obtain a stock solution of $1 \mathrm{mg} / \mathrm{ml}$ concentration and sterilized by filtration. Serial two fold dilutions were prepared from this for carrying out cytotoxic studies. 


\section{Determination of cell viability by MTT Assay}

The ability of the cells to survive a toxic medium has been the basis of most Cytotoxicity assays. This assay is based on the assumption that dead cells or their products do not reduce tetrazolium. The assay depends both on the number of cells present and on the mitochondrial activity per cell. The principle involved is the cleavage of tetrazolium salt 3-(4, 5 dimethyl thiazole-2-yl)-2, 5-diphenyl tetrazolium bromide (MTT) into a blue coloured product (formazan) by mitochondrial enzyme succinate dehydrogenase. The number of cells was found to be proportional to the extent of formazan production by the cells used.

The all compounds were evaluated for

Table 4: Cytotoxic activity of $\mathrm{Cu}$ (II) complexes of Schiff base molecular adducts against MCF-7 breast cancer cell line

\begin{tabular}{l}
$\begin{array}{l}\text { S. Compounds Test } \% \text { Cytotoxicity } \\
\text { No. }\end{array} \begin{array}{l}\text { CTC }_{50} \\
\text { Conc. } \\
(\mu \mathrm{g} / \mathrm{ml})\end{array}$ \\
\hline
\end{tabular}

\begin{tabular}{|c|c|c|c|c|}
\hline 1. & A & & $78.62 \pm 0.2$ & $145.22 \pm 8.9$ \\
\hline & & 1000 & $78.43 \pm 1.0$ & \\
\hline & & 500 & $76.04 \pm 0.6$ & \\
\hline & & 250 & $44.08 \pm 4.2$ & \\
\hline & & 125 & $19.52 \pm 5.9$ & \\
\hline & & 62.5 & & \\
\hline 2. & $\mathrm{~B}$ & 1000 & $78.68 \pm 0.3$ & $146.24 \pm 8.9$ \\
\hline & & 500 & $78.50 \pm 1.0$ & \\
\hline & & 250 & $76.06 \pm 0.6$ & \\
\hline & & 125 & $44.09 \pm 4.4$ & \\
\hline & & 62.5 & $19.58 \pm 6.0$ & \\
\hline 3. & C & 1000 & $78.65 \pm 0.4$ & $144.00 \pm 8.7$ \\
\hline & & 500 & $78.52 \pm 1.5$ & \\
\hline & & 250 & $76.06 \pm 0.8$ & \\
\hline & & 125 & $44.09 \pm 4.1$ & \\
\hline & & 62.5 & $19.52 \pm 5.3$ & \\
\hline 4. & $\mathrm{D}$ & 1000 & $78.76 \pm 0.34$ & \\
\hline & & 500 & $78.58 \pm 1.4$ & \\
\hline & & 250 & $76.24 \pm 0.5$ & $145.00 \pm 8.7$ \\
\hline & & 125 & $44.05 \pm 4.6$ & \\
\hline & & 62.5 & $19.56 \pm 5.9$ & \\
\hline 5. & $\mathrm{~F}$ & 1000 & $78.64 \pm 0.6$ & $145.20 \pm 8.8$ \\
\hline & & 500 & $78.50 \pm 1.5$ & \\
\hline & & 250 & $76.09 \pm 0.7$ & \\
\hline & & 125 & $44.09 \pm 4.6$ & \\
\hline & & 62.5 & $19.53 \pm 5.4$ & \\
\hline
\end{tabular}

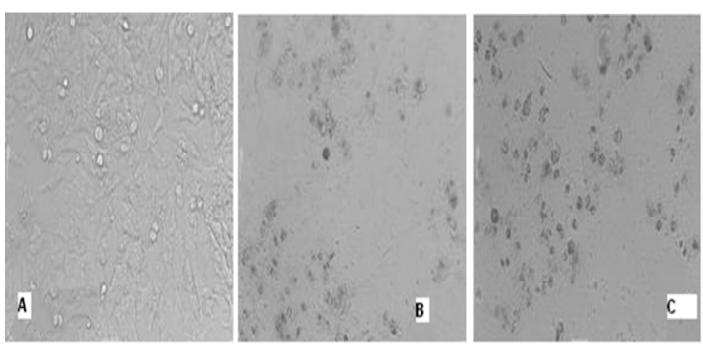

Fig. 2: Anti neoplastic activity of compound (a) (a) Control - MCF 7 (b) Compound a $1000 \mu \mathrm{g} / \mathrm{ml}$

(c) Compound a $500 \mu \mathrm{g} / \mathrm{ml}$

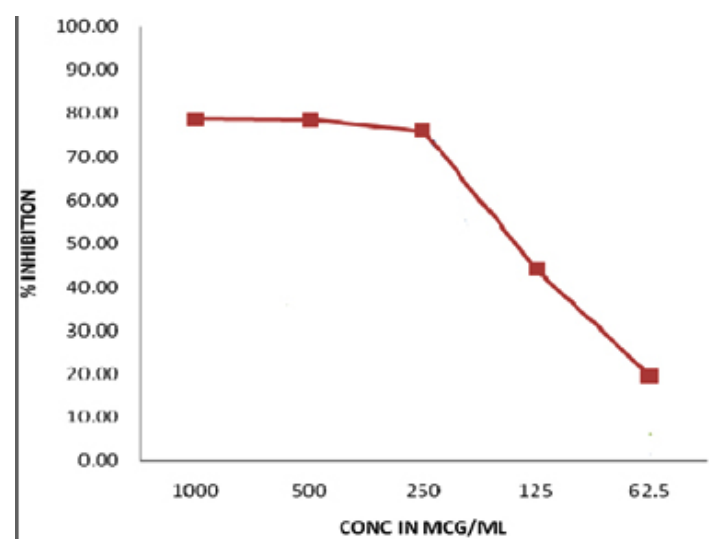

Fig. 3: Graph shows antineoplastic activity against MCF - 7 cell line

their effectiveness against the human breast cancer cell line MCF-7 using MTT cytotoxicity assay. For comparison purpose, the cytotoxicity of the standard anti-breast cancer drug Tamoxifen was used under the same experimental conditions. The $I_{50}$ value was calculated using MTT assay, as shown in Table 4 .The results revealed that the activity of compounds increases by the presence of bulky groups bonded to $\mathrm{N} 4$ of the ethylene di ammine moiety. The compounds were found to have high activity. The similarity in the values of $\mathrm{IC}_{50}$ for the $\mathrm{Cu}$ (II) complexes is evidence in favor of the same biochemical action mechanism. In fact, the literature reports that $\mathrm{Cu}$ (II) complexes of ethylene diammine derivatives are able to bind DNA in vitro and present enhanced capacity to form interstrand cross links as compared to cisplatin. Result revealed that compounds were exhibit potent activity against the MCF - cell line.

\section{In-vitro Antibacterial Activity}

The all copper (II) complexes were also evaluated for their potential antibacterial activity against B. subtilis (MTCC 1134), S. aureus (MTCC 
3160), E. coli (MTCC 50) and P. aeruginosa (MTCC 1034). Tables 5 highlight the antibacterial activity of complexes a-e against $B$. subtilis, S. aureus, E. coli and $P$. aeruginosa as observed by disc-diffusion method. The high antibacterial activity of copper (II) complexes may be due to coordination and chelation which tend to make copper complexes act as powerful and potent bacteriostatic agents, thus inhibiting the growth of the bacteria. In a complex, the positive charge on the copper is partially shared with the donor atoms present in the ligands and there may be delocalization of $ð$ electrons over the whole chelate. The increased activity of the metal chelates can be explained on the basis of chelation theory. The result of the this series revealed that the all copper (II) complexes contain significant antibacterial

Table 5: Invitro antibacterial activities of all compounds against gram positive and gram negative bacteria

\section{Compounds Zone of inhibition (in $\mathrm{mm}$ ) and Concentration $1 \mathrm{mg} / \mathrm{mL}$ of various strains \\ $\overline{E . \text { coli } P \text {. aerog B. subtilis S. aureus }}$ enosa}

\begin{tabular}{lcccc}
\hline A & 13 & 22 & 15 & 12 \\
$\mathrm{~B}$ & 14 & 25 & 15 & 13 \\
$\mathrm{C}$ & 9 & 18 & 6 & 8 \\
$\mathrm{D}$ & 10 & 16 & 5 & 6 \\
$\mathrm{E}$ & 8 & 10 & 10 & 9 \\
Tetracyclin & 10 & 6 & 20 & 22 \\
(Standard) & & & & \\
\hline
\end{tabular}

activity against two gram positive bacteria and two gram negative bacteria. All the copper (II) complexes exhibit higher antibacterial activity against the P. aurogenosa bacteria.

Table 4 revealed that all the copper (II) complexes exhibit significant activity against the tested two gram positive and two gram negative bacteria. The orders of antibacterial activity of the complexes against the E. coli are as follows Compound $\mathrm{c}>$ Compound $\mathrm{b}>$ Compound $\mathrm{a}>$ Compound e > Compound d

The orders of antibacterial activity of the complexes against the P. Aerogenosa are as follows Compound $\mathrm{c}>$ Compound a> Compound $b>$ Compound $d>$ Compound $e$. The orders of antibacterial activity of the complexes against the $B$. subtilis are as follows Compound $\mathrm{b}=\mathrm{c}>$ Compound $\mathrm{a}$ $=$ Compound $\mathrm{d}>$. The orders of antibacterial activity of the complexes against the $S$. aureus are as follows Compound $\mathrm{c}>$ Compound $\mathrm{b}>$ Compound $\mathrm{a}>>\mathrm{d}>\mathrm{e}$ . All the copper (II)

\section{In-vitro Antioxidant Activity of Copper (II)} Complexes of Schiff base molecular adducts

The copper (II) complexes have been suggested as promising agents for the diagnosis and treatment of different disease. All compounds showed significant free radical scavenging action against peroxide induced release of free radicals at varying concentrations $(200-1000 \mu \mathrm{g} / \mathrm{ml})$. Ascorbic acid was used as a reference standard. The \%

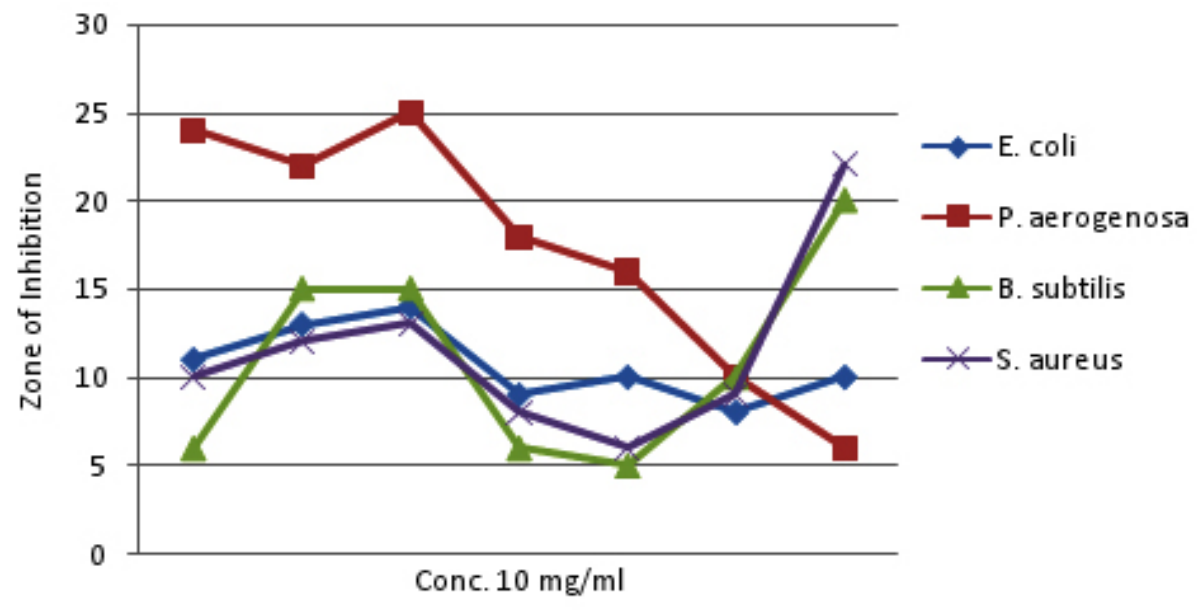

Fig. 4: Graph represents the antibacterial activity of $\mathrm{Cu}$ (II) complexes 
Table 6: In-vitro free radical scavenging effect of copper (II) complexes of Schiff base molecular adducts

\begin{tabular}{ccccccc}
\hline S.No. & Compounds & \multicolumn{5}{c}{$\%$ Scavenging of triplicates } \\
& & $\mathbf{2 0 0} \boldsymbol{\mu g} / \mathbf{m l}$ & $\mathbf{4 0 0} \boldsymbol{\mu g} / \mathbf{m l}$ & $\mathbf{6 0 0} \boldsymbol{\mu g} / \mathbf{m l} \mathbf{8 0 0} \boldsymbol{\mu g} / \mathbf{m l}$ & $\mathbf{1 0 0 0} \boldsymbol{\mu g} / \mathbf{m l}$ \\
\hline 1. & A & 25 & 39.5 & 45.3 & 46 & 74 \\
2. & B & 22.5 & 37.9 & 52.2 & 44.3 & 73.3 \\
3. & C & 14.6 & 34.13 & 57.3 & 42.5 & 72.0 \\
4 & D & 21.8 & 35.54 & 62.1 & 42.5 & 72.63 \\
5. & E & 20.17 & 35.67 & 60.1 & 42.65 & 72.63 \\
6. & Ascorbic acid & 50 & 65.4 & 68.2 & 75.3 & 80.6 \\
\hline
\end{tabular}

scavenging is shown in Table. In addition, some complexes have been suggested as a potential SOD mimics, mainly because of their high thermodynamic stability. 6 revealed that the all compounds showed the significant antioxidant activity at the concentration of $1000 \mu \mathrm{g} / \mathrm{ml}$.

The antioxidant activity of all the copper (II) complexes given in table 6 , the order of antioxidant activities of all complexes are as: Compound $\mathrm{b}>$ Compound $\mathrm{c}>$ Compound $\mathrm{f}=$ Compound e> Compound $d>$ Compound a. All the copper (II) complexes showed the significant antioxidant activity against. All the copper (II) complexes exhibit significant antioxidant activity but less than control ascorbic acid, compound e exhibit highest antioxidant activity due to the presence of nitro group in Schiff base molecular adduct.

\section{CONCLUSION}

This paper describes the Synthesis, Spectroscopic Characterization and Pharmacological Evaluation of Schiff Base molecular Adducts of Copper metal. . All Cu (II) compounds were synthesized and well characterized in detail by FTIR, 1HNMR, 13CNMR and LC-MS analysis. The $\mathrm{Cu}$ (II)compounds were in a distorted octahedral environment with the ligand having a tetradentate nitrogen chelating motif. All Cu (II) compounds showed significant in-vitro cytotoxic activity against human breast cancer cell lineMCF-7. Further studies would entail studying the in vitro cytotoxic effect of the complexes against other cancer celllines viz. lung, colon, ovarian etc., followed by in vivo studies in animal models as well as the in vitro effect of thecomplexes on various normal cell lines. More detailed studies are needed to understand the mechanisms of action at the cellular level and the role of the metal.Cell shrinkage and rounding, membrane blebbing, chromatin condensation and nuclear fragmentation are importantcharacteristics of apoptosis. In our study, prominent morphological changes, which are associated with apoptosisviz. live cell rounding, cell shrinkage and nuclear fragmentation, were observed when MCF-7 breast cancer cell line when treated with the compounds for $10 \mathrm{~h}$. The data reported in this article might prove helpful guide for medicinal chemists working in this area. Investigation of antibacterial screening data revealed that compounds exhibited significant antibacterial activityagainst $B$. subtilis, $P$. aerogenosa , S. aureus and E. coli. All compounds were found to possess potent antioxidant activity in the range of $80-90 \%$ when screened for their radical scavenging activity against DPPH compound. Many present day diseases are reported to be due to an impaired balance of the pro-oxidant-antioxidant homeostatic phenomenon in the body. Pro-oxidant conditions dominate either on account of increased generation of free radicals caused by excessive oxidative stress, or due to poor scavenging in the body caused by depletion of the dietary antioxidants. Reactive oxygen species differ significantly in their interactions and can cause extensive cellular damage such as nucleic acid strand scission, modification of polypeptides, lipid peroxidation etc . Antioxidants are the first line of defense against free radical damage, and are critical for maintaining optimum health. The need for antioxidants becomes even more critical with increased exposure to free radicals. As part of a healthy lifestyle and a well-balanced, wholesome diet, antioxidant supplementation is now being recognized as an important means of improving free radical protection. The macrocyclic ligands are highly significant in bioinorganic chemistry, catalysis 
as well as extraction of metal ions etc. Schiff base molecular adducts with transition metal ions show some interesting properties and biological functions such as being models for metallo proteinase and oxygen carrier systems. Keeping the above facts in mind and in continuation of our research work, the present paper reports the Synthesis, Spectroscopic Characterization and Pharmacological Evaluation of Schiff Base molecular Adducts of Copper metal These complexes have the potential to emerge as leading candidates for drug development, if studied and screened further for their in vivo effects.

\section{ACKNOWLEDGEMENTS}

The authors are thankful to the Chancellor, Vice Chancellor, Managing Director, ITM University, Gwalior, for their support and co-operation. RK is grateful to MPCST for providing financial assistance in the form of grant no. (Council order No. 4566/ Cst / $R$ \& D/2010).

\section{REFERENCES}

1. Z. Cimerman, S. Miljaniæ, and N. Galiæ, Croatica Chemica Acta, 2000, 73, 81-95,.

2. H. Schiff, Justus Liebigs Annalen Der Chemie. 1864, 131, 118-119.

3. D. N. Dhar and C. L. Taploo, Journal of Scientific and Industrial Research, 1982, 41, 8, 501-506.

4. B.S. Sathe, E. Jaychandran, V. A. Jagtap, and G. M. Sreenivasa, International Journal of Pharmaceutical Research and Development, 2011, 3, 164-169.

5. S. M. Sondhi, N. Singh, A. Kumar, O. Lozach, and L. Meijer, Bioorganic and Medicinal Chemistry, 2006, 14, 3758-3765.

6. Pandey, D. Dewangan, S. Verma, A. Mishra, and R. D. Dubey, "International Journal of ChemTech Research, 2011, 3, 178-184.

7. Chandramouli, M. R. Shivanand, T. B. Nayanbhai, B. Bheemachari, and R. H. Udupi, Journal of Chemical and Pharmaceutical Research, 2012, 4, 1151-1159.

8. R. P. Chinnasamy, R. Sundararajan, and S. Govindaraj, Journal of Advanced Pharmaceutical Technology and Research, 2010, 1, 342-347.

9. K. Mounika, B. Anupama, J. Pragathi, and C. Gyanakumari, Journal of Scientific Research, 2010, 2, 513-524.

10. P.Venkatesh, Asian Journal of Pharmaceutical and Health Sciences, 2011, 1, 8-11.

11. K. Chaubey and S. N. Pandeya," International Journal of PharmTech Research, 2012, 4, 590-598.

12. T. Aboul-Fadl, F. A. Mohammed, and E. A. Hassan," Archives of Pharmacal Research,
2003, 26,778-784.

13. R. Miri, N.Razzaghi-asl, and M.K. Mohammadi, Journal of Molecular Modeling, vol. 2013, 19,727-735.

14. S. M. M. Ali, M. Abul Kalam Azad, M. Jesmin et al., Asian Pacific Journal of Tropical Biomedicine, 2012, 2, 438-442.

15. Wei, N. Li, G. Lu, and K. Yao, Science in China $B, 2006,49,225-229$.

16. P. G. Avaji, C. H. Vinod Kumar, S. A. Patil, K. N. Shivananda, and C. Nagaraju, "European Journal of Medicinal Chemistry, 2009, 44, 3552-3559.

17. K. N. Venugopala and B. S. Jayashree, Indian Journal of Heterocyclic Chemistry, 2003,12, 4, 307-310.

18. K. Vashi and H. B. Naik, European Journal of Chemistry, 2004, 1, 272-276.

19. S. Li, S. Chen, S. Lei, H. Ma, R. Yu, and D. Liu, Corrosion Science, 1999, 41, 1273-1287,

20. Z. H. Chohan, M. Praveen, and A. Ghaffar, Metal-Based Drugs, 1997, 4, 267-272.

21. S. Ershad, L. Sagathforoush, G. KarimNezhad, and S. Kangari, International Journal of Electrochemical Science, 2009, 4, 846-854,

22. F. Tisato, F. Refosco, and G. Bandoli, Coordination Chemistry Reviews, 1994, 135 136, 325-397.

23. Jarrahpour, D. Khalili, E. De Clercq, C. Salmi, and J. M. Brunel, Molecules, 2007, 12, 1720-1730,

24. Bhattacharya, V. C. Purohit, and F. Rinaldi, Organic Process Research and Development, 2003, 7, 254-258. 
25. G. Bringmann, M. Dreyer, J.H. Faber, P.W. Dalsgaard, D. Staerk, J.W. Jaroszewski, et al. J Nat Prod, 2004, 67,743-74.

26. A.O. de Souza, F.C.S. Galetti, C.L. Silva, B. Bicalho, M.M. Parma, S.F. Fonseca, et al. Quim Nova, 2007, 30, 1563-1566.

27. Z. Guo, R. Xing, S. Liu, Z. Zhong, X. Ji, L. Wang, et al. Carbohydr Res, 2007, 342,
1329-1332.

28. Y. Zheng, K. Ma, H. Li, J. Li, J. He, X. Sun, et al. Catal Lett, 2009, 128 (3-4), 465-474.

29. R.B. Moffett, N. Rabjohn (Ed.), Organic syntheses, John Wiley \& Sons, Inc., New York (USA) 1963, 4, 605-608.

30. K. Taguchi, F.H. J Org Chem, 1971, 36, 1570-1572. 